\title{
INFLUENCE OF PHOTOPERIOD ON THIAMINE, RIBOFLAVIN AND NIACIN CONTENT OF GREEN PLANTS ${ }^{1}$
}

\author{
Felix G. Gustafson
}

IT IS A WELL KNOWN FACT that the climate and the seasons influence the vitamin content of green plants. Many investigators, among them Wolf (1938), Moldtmann (1939), Reid (1941, 1942), Hamner et al. (1944), Rodahl (1944), Åberg (1946), Somers et al. (1948), and Gustafson (1948, 1950), have shown that both light and temperature are factors of great importance in vitamin synthesis. Yet when light intensity and temperature have been accounted for there is still something lacking to account for the high vitamin content of plants during the summer.

In 1940 Bonner found that Xanthium pennsylvanicum, Cosmos sulfureus, Lycopersicum esculentum, Brassica nigra and $B$. alba had a higher concentration of thiamine in the leaves when subjected to a photoperiod of 18-20 hr. than when exposed to a 9-hr. photoperiod. Reid (1942) found that medium to long days were conducive to the production of a high ascorbic acid content in cow peas, whereas short photoperiods produced plants with low ascorbic acid content. Hamner et al. (1944) also found that the tomato produced less ascorbic acid under an 8-hr. photoperiod than when exposed to a 16-hr. photoperiod.

In the spring of 1951 the writer had the opportunity of spending several months at the Earhart Plant Research Laboratory at the California Institute of Technology, Pasadena, California, and it was decided to take advantage of the unusual opportunity offered at this laboratory to study the influence of the photoperiod on vitamin content in several different plants.

Material AND METHODS.-The plants used for these studies were Alaska peas, Black Valentine beans and San Jose Canner tomatoes. The plants were grown in natural light at day temperature of 23 or $26^{\circ} \mathrm{C}$., and a photoperiod of 14-15 hr. until placed under the experimental conditions. The age of the plants varied considerably but within any one experiment the plants used were of the same age and were closely selected for size and stage of development. The plants were grown in plastic boxes in gravel and vermiculite, and were watered with Hoagland's nutrient solution. In the first experiments the plants were transferred directly from the greenhouse to the experimental rooms, but in the later experiments they were first placed in the

\footnotetext{
1 Received for publication June 18, 1952.

Paper from the Department of Botany of the University of Michigan, No. 969. This investigation has been aided financially by the U. S. Public Health Service. Much of the work was done at the Earhart Plant Research Laboratory of the California Institute of Technology, and the writer wishes to express his appreciation for the courtesies extended him by the Institute and by Dr. F. W. Went.
}

dark at $20^{\circ} \mathrm{C}$. and left there for various lengths of time, to reduce the vitamin content before setting up the experiment.

During the controlled part of an experiment the plants were maintained day and night at the designated temperature. The temperatures chosen for these experiments were $6^{\circ}, 14^{\circ}, 20^{\circ}$ and $26^{\circ} \mathrm{C}$., and the plants were exposed for 8,16 and $24 \mathrm{hr}$. out of every $24 \mathrm{hr}$. to artificial light of an intensity of from 1000-1600 ft.-c. (See Went, 1950, for details of lighting). In each experiment the light intensity was the same at all temperatures except for a second lot of plants at $26^{\circ} \mathrm{C}$., which received a light intensity of about $600-700 \mathrm{ft} .-\mathrm{c}$.

For thiamine and riboflavin analyses the plant material was harvested at 1:00-3:00 p.m., quickly frozen and shipped in dry ice by air to Ann Arbor, Michigan, where the material was received in less than 24 hr., still in a frozen condition. On receipt the plants were put in a deep freezer at $-20^{\circ} \mathrm{C}$. and analyzed within a few days. The first niacin analyses were made in Pasadena and later ones in Ann Arbor on the same material that was used for the other vitamins. Preliminary tests had shown that the three vitamins under investigation were not destroyed by this freezing treatment. Plants were left for several weeks in the deep freezer without any decrease in vitamin content. The niacin analyses made in Pasadena were made on plants similar to those shipped to Ann Arbor, and were collected one day later and analyses made at once on fresh material. All experiments on the tomato were made with plants from the same planting, so that as the investigation progressed the plants became older and older. This necessitated using fewer plants and less of each plant. To clarify the situation details of the different experiments with the tomato plant are given in table 1 .

The thiamine and riboflavin analyses were made according to the procedure outlined by the author in 1947, with a modification according to which digestion with clarase is carried out at a temperature of $37^{\circ} \mathrm{C}$. for $20 \mathrm{hr}$. instead of at $45^{\circ} \mathrm{C}$. for $2 \mathrm{hr}$. Precautions were taken to prevent bacterial contamination. The niacin assay followed the prescribed procedure, as given in the Methods of Vitamin Assay issued by the Association of Vitamin Chemists (1947).

RESULTS.-In table 2 are given the results for thiamine. Only one experiment was run with peas and these plants were 20 days old. They were main. tained under the experimental conditions for 6 days and the light intensity was about $1000 \mathrm{ft}$.-c. At the two lower temperatures there was a decrease in thiamine with increase in length of the photo- 
TABLE I. Details of treatment of the tomato plant material used.

\begin{tabular}{|c|c|c|c|c|c|}
\hline Exp. & $\begin{array}{l}\text { No. plants used } \\
\text { for each photop. }\end{array}$ & Part used & $\begin{array}{l}\text { Age in } \\
\text { days }\end{array}$ & $\begin{array}{l}\text { Light intensity } \\
\text { ft.-c. }\end{array}$ & $\begin{array}{l}\text { No. of days } \\
\text { under exp. } \\
\text { conditions }\end{array}$ \\
\hline $354^{2}$ & 6 & All leaves and 1 in. stem tip. & 37 & $1300-1600$ & 5 \\
\hline 356. & 4 & 5 leaves and 1 in. stem tip. & 44 & $1000-1400$ & 6 \\
\hline 358 & 4 & Blades from 7 leaves and 1 in. tip. & 51 & $1400-1500$ & 6 \\
\hline 360 & 4 & As for 358 & 53 & $1100-1500$ & 5 \\
\hline
\end{tabular}

"In the first three experiments the plants were transferred directly from the greenhouse to the experimental rooms, but in the last one the plants were transferred from the greenhouse to a dark room at $20^{\circ} \mathrm{C}$., where they were left continuously for 5 days, previous to being placed in the experimental rooms.

period, but at $20^{\circ} \mathrm{C}$. there was no definite trend. Entire tops of 15 to 21 plants from each condition were used.

The tomato plants maintained at the temperatures $6^{\circ}, 14^{\circ}$ and $20^{\circ} \mathrm{C}$. show no significant response to the photoperiod, except those in experiment 360 , which were starved by being placed in the dark for several days preparatory to the exposure to different photoperiods. On the other hand, plants at $26^{\circ} \mathrm{C}$. showed a decrease in thiamine with lengthening of the photoperiod. This is true for both light intensities. In the starved plants there was a decrease in vitamin with increase in photoperiod, at temperatures $14^{\circ}$ and $20^{\circ} \mathrm{C}$., similar to that in the plants at $26^{\circ} \mathrm{C}$. Analyses of the plants before they were placed in the dark and after 5 days in the

TABLE 2. Influence of photoperiod at different temperatures on the thiamine content in peas, tomato and bean plants. Vitamin content is given in $\mu g . / g$. fresh weight. ${ }^{a}$

\begin{tabular}{|c|c|c|c|c|c|c|c|}
\hline \multirow{2}{*}{$\begin{array}{l}\text { Photo- } \\
\text { period } \\
\text { Experime }\end{array}$} & \multirow{2}{*}{$\begin{array}{l}\text { Temper- } \\
\text { ature } \\
\text { ent No. }\end{array}$} & \multirow{2}{*}{$\begin{array}{c}\text { Peas } \\
350\end{array}$} & \multicolumn{4}{|c|}{ Tomatoes } & \multirow{2}{*}{$\begin{array}{r}\text { Beans } \\
364\end{array}$} \\
\hline & & & 354 & 356 & 358 & 360 & \\
\hline Hr. & ${ }^{\circ} \mathrm{C}$. & & & & & & \\
\hline 8 & 6 & 0.75 & 0.60 & 0.89 & 1.14 & 0.89 & 0.77 \\
\hline 16 & 6 & 0.71 & 0.71 & 0.71 & 1.17 & 0.75 & 0.73 \\
\hline 24 & 6 & 0.59 & 0.63 & 0.65 & 1.19 & 0.86 & 0.85 \\
\hline 8 & 14 & 0.80 & 0.77 & 0.71 & 1.31 & 1.27 & 0.65 \\
\hline 16 & 14 & 0.79 & 0.74 & 0.92 & 1.00 & 1.00 & 0.65 \\
\hline 24 & 14 & 0.62 & 0.60 & 0.81 & 0.98 & 0.63 & 0.67 \\
\hline 8 & 20 & 0.78 & 0.76 & 0.73 & 1.06 & 1.21 & 0.82 \\
\hline 16 & 20 & 0.70 & 0.69 & 0.85 & 1.06 & 1.32 & 0.59 \\
\hline 24 & 20 & 0.85 & 0.73 & 0.77 & 0.85 & 1.03 & 0.65 \\
\hline 8 & 26 & & 0.74 & 1.17 & 1.45 & 1.27 & 0.82 \\
\hline 16 & 26 & & 0.73 & 1.08 & 1.46 & 1.09 & 0.68 \\
\hline 24 & 26 & & 0.57 & 0.79 & 0.96 & 0.92 & 0.58 \\
\hline 8 & 26 & & $0.60^{b}$ & 1.06 & 1.47 & & \\
\hline 16 & 26 & & 0.57 & 0.92 & 1.10 & & \\
\hline 24 & 26 & & 0.52 & 0.60 & 1.00 & & \\
\hline
\end{tabular}

${ }^{a}$ A five per cent difference between readings of an experiment can usually be considered significant, when material is carefully selected as was the case here.

b The second group of plants at $26^{\circ} \mathrm{C}$. in experiments 354 , 356 , and 358 were at light intensities of about $600-700$ ft.-c., whereas the ones above were at light intensities of from $1000-1600 \mathrm{ft} .-\mathrm{c}$. in the different experiments. dark showed considerable decrease in the thiamine content. This shows up even after 5 days at $6^{\circ} \mathrm{C}$.

In the single experiment with beans the plants were also first subjected to a dark period before placing them under the experimental conditions. As in the experiment with the tomato, $26^{\circ} \mathrm{C}$. was the only temperature at which the photoperiod influenced the thiamine content and here too the longest photoperiod produced plants with the lowest vitamin content. For each condition six 24-day-old plants were used. The stems were cut just below the cotyledonary node and everything above this cut, except the cotyledons, was used.

In table 3 the results for riboflavin are recorded. The thiamine and riboflavin were determined on the same plant material. The most striking thing about riboflavin is that, unlike thiamine, there is an increase in amount with increase in the photoperiod, when there is a significant effect at all.

The pea plants from temperatures $14^{\circ}$ and $20^{\circ} \mathrm{C}$. show a progressive increase in riboflavin with the increase in photoperiod. At $26^{\circ} \mathrm{C}$. the plants were damaged and they were not used. In other experiments where effect of temperature on peas was studied, they died most rapidly at $26^{\circ} \mathrm{C}$., which is, of course, not surprising, as we know that peas are a cool weather crop.

Tomato plants, at temperatures $14^{\circ}, 20^{\circ}$ and $26^{\circ} \mathrm{C}$., demonstrated a general progressive increase in riboflavin with increase in the length of photoperiod. In plants at $26^{\circ} \mathrm{C}$. that were exposed to light intensities lower than $1000 \mathrm{ft}$.c., this increase with the lengthening of the day was less marked or entirely absent. In beans there was no significant difference in the riboflavin content with change in photoperiod. This was true for all temperatures.

Niacin was determined in two different lots of pea plants. At both ages the niacin content increased at all temperatures, as the length of photoperiod increased (table 4). In both experiments entire tops of 15-20 plants were used.

No general statement will cover the niacin situation in the tomato plants. When the concentration was plotted against photoperiod it was observed that in the majority of cases there was a dip at the 16-hr. photoperiod, but there were a few exceptions. The 
TABLE 3. Influence of photoperiod at different temperatures on the riboflavin content in pea, tomato and bean plants. Vitamin content is given in $\mu \mathrm{g} . / \mathrm{g}$. fresh weight.

\begin{tabular}{rrrrrrrrr}
\hline $\begin{array}{r}\text { Photo- } \\
\text { period }\end{array} \begin{array}{c}\text { Temper- } \\
\text { ature }\end{array}$ & $\begin{array}{c}\text { Peas } \\
\text { Experiment }\end{array}$ & No. & 350 & 354 & 356 & 358 & 360 & 364 \\
\hline Hr. & ${ }^{\circ}$ C. & & & & & & & \\
8 & 6 & 1.25 & 1.83 & 1.71 & 3.08 & 2.48 & 1.37 \\
16 & 6 & 1.18 & 1.83 & 1.47 & 2.84 & 2.18 & 1.30 \\
24 & 6 & 1.15 & 1.87 & 1.38 & 2.80 & 2.34 & 1.57 \\
8 & 14 & 0.70 & 1.69 & 1.25 & 2.64 & 2.79 & 1.20 \\
16 & 14 & 0.89 & 1.90 & 1.44 & 2.80 & 2.76 & 1.36 \\
24 & 14 & 0.95 & 2.13 & 1.60 & 2.79 & 3.18 & 1.39 \\
8 & 20 & 0.73 & 1.22 & 1.16 & 2.26 & 2.02 & 0.97 \\
16 & 20 & 0.96 & 1.70 & 1.29 & 2.46 & 2.19 & 0.98 \\
24 & 20 & 1.23 & 1.83 & 1.63 & 3.19 & 2.60 & 1.22 \\
8 & 26 & & 1.24 & 1.71 & 2.68 & 2.14 & 1.14 \\
16 & 26 & & 1.29 & 2.14 & 2.72 & 2.14 & 1.33 \\
24 & 26 & & 1.87 & 1.95 & 2.86 & 2.72 & 1.32 \\
8 & 26 & & $1.13^{\mathrm{a}}$ & 2.08 & 2.54 & & \\
16 & 26 & & 1.43 & 2.07 & 2.72 & & \\
24 & 26 & & 1.41 & 2.22 & 2.86 & & \\
\hline
\end{tabular}

The second group of plants at $26^{\circ} \mathrm{C}$. in experiments 354 , 356 , and 358 were at light intensities of about $600-700 \mathrm{ft}$.-c., whereas the first lot was at $1000-1600 \mathrm{ft}$.-c. in the different experiments.

youngest plants (experiment 9) did not conform to this picture, but in this experiment whole plants were used, whereas in others only leaves or even leaf blades were employed. This may make quite a difference as stems and petioles do not synthesize any vitamins (Gustafson, 1947). The best experiment is 360 , where the plants were first starved before being placed under the controlled conditions. In this experiment the plants subjected to the 24-hr. photoperiod have the highest niacin concentration except at $6^{\circ} \mathrm{C}$.

The bean plants were also subjected to darkness at $20^{\circ} \mathrm{C}$. for 4 days and during this period there was a considerable decrease in niacin so that at the time they were placed under controlled conditions the niacin was down to $7.35 \mu \mathrm{g}$./g. of fresh weight. The very great increase at $6^{\circ} \mathrm{C}$. was not expected. In previous experiments (Gustafson, 1950) it had been shown that beans at temperatures $10-15^{\circ} \mathrm{C}$. produced less vitamin than at higher temperatures. Continuous lighting is conducive to high niacin content at all temperatures.

Discussron.- In this investigation twelve combinations of temperatures and photoperiod have been employed, whereas in other investigations the plants were subjected to only one temperature and two photoperiods. Whatever temperature is considered with 8- and 16-hr. photoperiods, we find only six instances out of twenty-six combinations in which thiamine is even slightly higher for the 16-hr. than for the 8-hr. photoperiod, and in all others the concentration in the plants exposed to the 8-hr. photoperiod was considerably higher than in those from the 16- or 24-hr. photoperiod. One might, therefore, consider that if the length of day has any effect on the thiamine concentration at all, a long day is more likely to cause a decrease than an increase. This is contrary to what Bonner (1940) found for thiamine and what others have found for ascorbic acid. This difference cannot be explained on the basis of the plants in the long days being more succulent than those in short days. No dry weight determinations were made on these plants, but in other investigations the writer has found no essential difference in dry weight between plants exposed to 8-hr. photoperiod and I6-hr. photoperiod. At all temperatures investigated, the plants grew more in the longer photoperiods. This need not surprise one as thiamine is not known to be directly related to growth.

In determinations at the temperatures $14^{\circ}, 20^{\circ}$ and $26^{\circ} \mathrm{C}$., where there was any appreciable difference in plants from the different photoperiodic treatments, the plants from continuous light had the highest riboflavin content. In most cases this was quite appreciable, especially in those plants where there had been some depletion, due to dark treatment, before the plants were put under the controlled conditions. The plants from $6^{\circ} \mathrm{C}$. gave very unsatisfactory results. The differences among the photoperiods are not very large, but sometimes the shortest photoperiod has the highest concentration while at other times the reverse is true. Part of this irregularity may be due to the fact that in the first four experiments the plants were transferred directly from the greenhouse at $23^{\circ} \mathrm{C}$. and these plants were quite rich in riboflavin. At the low

TABLE 4. Influence of photoperiod at different temperatures on the niacin content in pea, tomato and bean plants. Vitamin content is given in $\mu g . / g$. fresh weight.

\begin{tabular}{|c|c|c|c|c|c|c|c|c|}
\hline \multirow{2}{*}{$\begin{array}{l}\text { Photo- } \\
\text { period } \\
\text { Experi }\end{array}$} & \multirow{2}{*}{$\begin{array}{l}\text { Tem- } \\
\text { pera- } \\
\text { ture } \\
\text { iment }\end{array}$} & \multicolumn{2}{|c|}{ Peas } & \multicolumn{4}{|c|}{ Tomatoes } & \multirow{2}{*}{$\begin{array}{c}\text { Beans } \\
364\end{array}$} \\
\hline & & No. $\overline{7}$ & 8 & 9 & 10 & 11 & 360 & \\
\hline Hr. & ${ }^{\circ} \mathrm{C}$. & & & & & & & \\
\hline 8 & 6 & $8.50^{\mathrm{a}}$ & 7.72 & 6.24 & 10.12 & 13.25 & 13.13 & 12.83 \\
\hline 16 & 6 & 8.98 & 8.21 & 5.60 & 9.50 & 11.38 & 12.14 & 13.13 \\
\hline 24 & 6 & 9.75 & 8.85 & 5.87 & 9.50 & 11.50 & 12.24 & 13.33 \\
\hline 8 & 14 & 7.05 & 5.43 & 4.38 & 7.05 & 11.25 & 13.14 & 7.84 \\
\hline 16 & 14 & 8.36 & 5.77 & 5.35 & 7.46 & 9.48 & 10.98 & 8.38 \\
\hline 24 & 14 & 8.94 & 6.50 & 6.39 & 9.00 & & 14.83 & 8.29 \\
\hline 8 & 20 & 7.71 & 5.94 & 4.08 & 6.67 & 9.61 & 9.55 & 8.17 \\
\hline 16 & 20 & 7.92 & & 4.73 & 6.00 & 9.40 & 9.17 & 7.51 \\
\hline 24 & 20 & 9.35 & 8.32 & 5.10 & 8.56 & 11.70 & 10.79 & 9.88 \\
\hline 8 & 26 & & & 5.81 & 7.10 & 12.00 & 8.58 & 9.75 \\
\hline 16 & 26 & & & 4.65 & 6.56 & 9.50 & 8.36 & 9.53 \\
\hline 24 & 26 & & & 3.76 & 8.10 & 13.81 & 11.79 & 10.48 \\
\hline
\end{tabular}

"The niacin analyses for experiments $7,8,9,10$ and 11 were made at Pasadena, but on material that was essentially the same as that used for thiamine and riboflavin and sent to Ann Arbor, Michigan. Experiments 360, and 364 are identical with the same numbers for thiamine and riboflavin and were made at Ann Arbor at the time the others were made. 
temperature this was only slowly modified by the photoperiod. In the last two experiments where the plants were first starved, the longest photoperiod always had the highest riboflavin content. Here high riboflavin content and a high rate of growth are associated. Riboflavin has sometimes been called a growth vitamin.

Niacin increased progressively with increase of day length, in peas. In tomato there is, in general, a slight increase in niacin content with increase in the photoperiod. This is especially true for the higher temperatures. Beans had the highest niacin content in the longest photoperiod at $6^{\circ}, 20^{\circ}$ and $26^{\circ} \mathrm{C}$., but at $14^{\circ} \mathrm{C}$. there was no essential difference between 16-hr. and 24-hr. photoperiods.

\section{SUMMARY}

In this investigation thiamine, riboflavin and niacin content has been determined in the Alaska pea, Black Valentine bean and the San Jose Canner tomato, when subjected to 8-, 16- and 24-hr. photoperiods. It has been found that, in general, at temperatures $14^{\circ}, 20^{\circ}$ and $26^{\circ} \mathrm{C}$., there was a decrease in thiamine content as the plants were exposed to longer photoperiods. On the contrary, riboflavin and niacin concentrations increased with increase in the length of photoperiod.

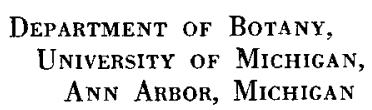

\section{LITERATURE CITED}

A BERG, B. 1946. Effect of light and temperature on ascorbic acid content of green plants. Ann. Roy. Agric. Coll. Sweden 15: 239-273.

Association of Vitamin Chemists, Inc. 1947. Methods of vitamin assay. Interscience Publisher, Inc. New York.

BONNER, J. 1940. Experiments on photoperiod in relation to the vegetative growth of plants. Plant Physiol. 15: 319-325.

Gustafson, F. G. 1947. Distribution of thiamin and riboflavin in the tomato plant. Plant Physiol. 22: 620-627.

-1 1948. Influence of light intensity upon the concentration of thiamin and riboflavin in plants. Plant Physiol. 23: 373-378.

- 1950. Influence of temperature in the vitamin content of green plants. Plant Physiol. 25: 150-159.

Hamner, K. C., L. Bernstein, and L. A. Maynard. 1944. Effect of light intensity, day length, temperature and other environmental factors on the ascorbic acid content of tomatoes. Jour. Nutrition 29: 85.96.

Moldtmann, H. G. 1939. Untersuchungen über den Ascorbinäuregehalt der Pflanzen in seiner Abhangigkeit von inneren und äusseren Factorem. Planta 30: 297 342.

ReID, Mary E. 1941. Relation of temperature to the ascorbic acid content of cow pea seedlings. Bull. Torrey Bot. Club 68: 519-530.

1942. Effect of variation in light intensity, length of photoperiod, and availability of nitrogen upon accumulation of ascorbic acid in cow pea plants. Bull. Torrey Bot. Club 69: 204-220.

Rodahl, K. 1944. Content of vitamin C (1-ascorbic acid) in arctic plants. Trans. and Proc. Bot. Soc. Edinburgh 34: 205-210.

Somers, G. F., W. C. Kelley, and K. C. Hamner. 1948. Changes in ascorbic acid content of turnip-leaf discs as influenced by light, temperature and carbon dioxide concentration. Archiv. Biochem. 18: 59-67.

Went, F. W. 1950. The Earhart Plant Research Laboratory. Chronica Botanica 12:89-108.

WoLf, J. 1938. Ueber Schwankungen des Gehaltes an Ascorbinsäure in abgeschnittenen Blättern von Bryophyllum calycinum bei verschiedenen 'Temperature. Planta 28: 725.729. 